\title{
Uptake of radionuclides by spring wheat and barley from cultivated soils supplemented by contaminated sewage sludge
}

\author{
Marketta PUhaKainen and ToIvo Yläranta
}

PUHAKAINEN, M. \& YLÄRANTA, T. 1992. Uptake of radionuclides by spring wheat and barley from cultivated soils supplemented by contaminated sewage sludge. Agric. Sci. Finl. 1: 27-36. (Finnish Centre for Radiation and Nuclear Safety, Box 268, SF-00101 Helsinki, Finland and Agric. Res. Centre of Finland, Inst. Environ. Res. SF31600 Jokioinen, Finland.)

\begin{abstract}
After the accident at the Chernobyl nuclear power station in April 1986, large amounts of fallout radionuclides originating from Chernobyl were measured in sewage sludge in Finland. Field experiments were performed to evaluate the amount of activity of fallout nuclides transferred from soil to spring wheat and barley grown in fields supplemented by contaminated sewage sludge and further to calculate the soil-grain transfer factors.

The experiments were conducted in southern Finland on clay, clay loam and sandy loam soil. The digested sludge was spread on fields, at a ratio of 22 tons of dry matter per hectare. The sludge formed in 1986 was spread in spring 1987 on ploughed fields before the preparation of the seedbed, or in autumn 1987 prior to ploughing. The different plots were fertilized with NPK fertilizer so that the amount of available nutrients was about equal in all treatments.

Application of sludge increased the concentration of ${ }^{137} \mathrm{Cs}$ in grain 2-12 times as compared with crops grown in plots without sewage sludge addition.

The transfer factor of ${ }^{137} \mathrm{Cs}$ from soil to plant defined as $\mathrm{Bq} \mathrm{ha}^{-1}$ in plant (grain and straw) per $\mathrm{Bq} \mathrm{ha}^{-1}$ in soil (and sludge) varied in the first experimental years (1987 and 1988) from $20 \times 10^{-6}$ to $150 \times 10^{-6}$ and in the second experimental years (1988 and 1989) from $6 \times 10^{-6}$ to $50 \times 10^{-6}$ for sludge treated soil and from $10 \times 10^{-6}$ to $60 \times 10^{-6}$ and from $8 \times 10^{-6}$ to $50 \times 10^{-6}$ for soil without sludge addition, respectively.
\end{abstract}

Key words: ${ }^{137} \mathrm{Cs},{ }^{134} \mathrm{Cs}$, sewage sludge, spring wheat, barley

\section{Introduction}

After the accident at the Chernobyl nuclear power station in April 1986, large amounts of fallout radionuclides originating from Chernobyl were measured in sewage sludge in Finland (PuHAKAINEN et al. 1987). The highest measured ${ }^{137} \mathrm{Cs}$ activity was $12000 \mathrm{~Bq} \mathrm{~kg}^{-1}$ dry matter (compared to ${ }^{137} \mathrm{Cs}$ activities in sludge varying from $0-20 \mathrm{~Bq} \mathrm{~kg}^{-1}$ dry matter before the accident) (PUHAKAINEN 1986). Yearly $1100000 \mathrm{~m}^{3}$ dewatered sewage sludge is produced in Finland. Of this, $75 \%$ is utilized; $50 \%$ in agriculture and $25 \%$ for landscaping.

The maximum amount of sludge recommended for agricultural use was at that time 20 metric tons of dry matter per hectare. If the maximum amount of sludge accumulated in 1986 would have been spread on the fields, the increase of radioactivity would at most have been $24000 \mathrm{~Bq} \mathrm{~m}^{-2}$.

In 1987, field experiments were started to evaluate the amount of activity of fallout nuclides 
transferred from soil to spring wheat and barley grown in fields supplemented by sewage sludge. Knowledge of the interaction between sludge, soil and plants is required when recommendations regarding the utilization of sludge for agricultural purposes are given in the future. The experiments were conducted at the Agricultural Research Centre of Finland at Jokioinen in southern Finland in 1987 1989 on a clay, a clay loam and a sandy loam soil.

\section{Material and methods}

\section{The sludge used in the experiments}

In the experiment dewatered digested sludge from the Kyläsaari wastewater treatment plant in Helsinki was used. Kyläsaari is the largest treatment plant in Finland, with over $100 \mathrm{~m}^{3}$ of digested dewatered sludge being produced daily (LUNDSTRÖM 1987).

After the accident the activity concentrations of the sludge in Kyläsaari were at most above $5000 \mathrm{~Bq}$ $\mathrm{kg}^{-1}$ dry weight. About half of this activity was due to the precipitate coming from a water treatment plant. The flocculation with aluminium sulphate at surface water treatment plants during water purification was found to concentrate radionuclides originating from fallout relatively efficiently. This precipitate was pumped into the sewer system. A small amount of the precipitate rich in radionuclides doubled the concentration of ${ }^{137} \mathrm{Cs}$ in the sewage sludge (PUHAKAINEN et al. 1987).

The sludge formed in spring 1986 was used for the field experiments. The ${ }^{137} \mathrm{Cs}$ activity concentration in the sludge used was $5300 \mathrm{~Bq} \mathrm{~kg}^{-1}$ dry matter in experiment 1 and $4700 \mathrm{~Bq} \mathrm{~kg}^{-1}$ dry matter in experiment 2, and the ratio ${ }^{134} \mathrm{Cs} /{ }^{137} \mathrm{Cs}$ was 0.6 (ref. day 1. May, 1986). The dry matter content in the dewatered sludge was $22 \%$ and $\mathrm{pH}\left(\mathrm{H}_{2} \mathrm{O}\right) 6.9$. The chemical composition of the sewage sludge is given in Table 1.

Extraction of radionuclides from the sewage sludge and precipitate with aluminium sulphate was done with acid ammonium acetate solution ( $\mathrm{pH} \mathrm{4.65).} \mathrm{The} \mathrm{extraction} \mathrm{time} \mathrm{was} 1 \mathrm{~h}$ and the sludge to solution ratio $1: 10(\mathrm{v} / \mathrm{v})$ (VUORINEN and MÄKITIE 1955). The activity of liquids and residuals were measured by $\mathrm{Ge}(\mathrm{Li})$ gammaspectrometry. The extractability of radiocesium from the sewage sludge was $3-5 \%$ and from the precipitate with Al-sulphate about $3 \%$. The precipitate was also frozen and defrozen before extraction. The freezing did not change the extractability of radiocesium (ToIVANEN 1987).

Table 1. The chemical composition of sewage sludge on a dry weight basis made by Soil Analysis Service Ltd. Analysed according to Finnish requirements (Ympäristöministeriö 1991).

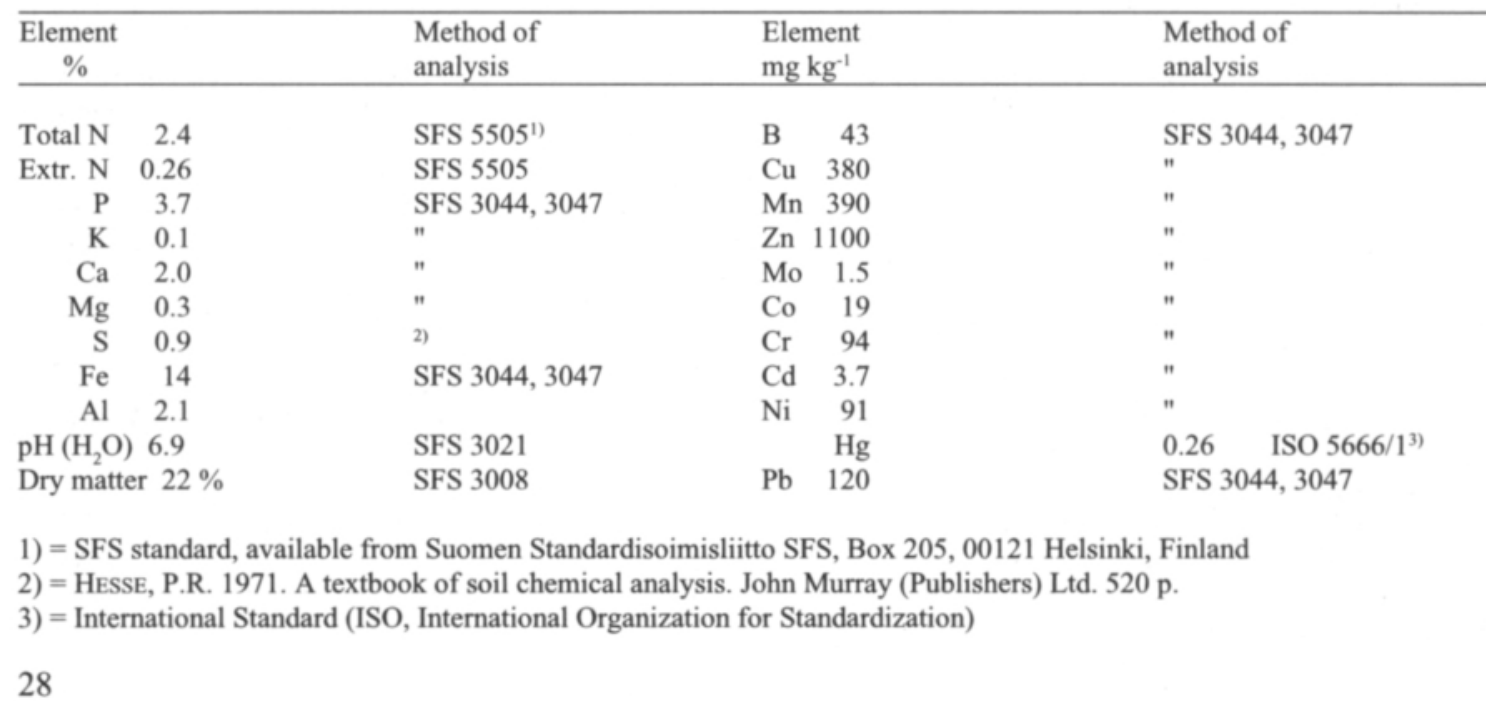




\section{Field experiments}

The field experiments were conducted during two growing seasons on a clay, a clay loam and a sandy loam soil. The crops were spring wheat (cv. Ruso) and barley (cv. Kustaa). The size of the experimental plots was $2.5 \mathrm{~m} \times 15 \mathrm{~m}$, replicated four times.

The sludge formed in spring 1986 was spread in spring 1987 on ploughed fields before the preparation of the seedbed (experiment 1) or in autumn 1987 prior to ploughing (experiment 2). The amount of sludge used was $100 \mathrm{~m}^{3}$ per hectare. This amount contained 22 metric tons of dry matter per hectare.

The plots where no sludge was added were fertilized at a rate of $600 \mathrm{~kg}$ per hectare with a NPK fertilizer containing $16 \%$ N, $7 \% \mathrm{P}$ and 13.3 $\% \mathrm{~K}$. To the plots to which sewage sludge was added also $200 \mathrm{~kg}$ per hectare of a NPK fertilizer containing $20 \% \mathrm{~N}, 4.4 \% \mathrm{P}, 8.3 \% \mathrm{~K}$ was added. Hence, the amounts of plant available nutrients were about equal in all treatments. The residual effect of sewage sludge applications was studied in 1988 and 1989, respectively. Samples were taken from soil, sludge, grain and straw.

Soil samples were taken before addition of sludge and cored to depths of $0-20 \mathrm{~cm}$ and $20-40$ $\mathrm{cm}$. The samples were dried at $35^{\circ} \mathrm{C}$, and ground, avoiding disintegration of primary particles, through a 2-mm sieve and analyzed for volume weight, $\mathrm{pH}\left(\mathrm{CaCl}_{2}\right)$ (TARES and SiPPOLA 1978), content of organic carbon (SIPPOLA 1982) and gammaradionuclides (Table 2). The $\mathrm{pH}$ was measured in $0.01 \mathrm{M} \mathrm{CaCl}_{2}$ suspension at the soil to solution ratio of 1:2.5 (TARES and SIPPOLA 1978). The measurements of radioactivity concentrations were carried out at the Finnish Centre for Radiation and Nuclear Safety. The samples were packed in Marinelly beakers (volume 0.6 l) and measured by low background $\mathrm{Ge}(\mathrm{Li})$ gammaspectrometry.

Grains and straws collected in 1987 were measured by direct gamma measurement in Marinelly geometry. In 1988, the activity concentrations were so low that some of the samples

Table 2. The mean concentration and ranges of ${ }^{134} \mathrm{Cs},{ }^{137} \mathrm{Cs},\left(\mathrm{Bq} \mathrm{kg}^{-1}\right.$ dry matter $)$ and the value of pH and volume weight and content of clay and soil organic carbon in dry soil before the sludge was added. ref. day 1.10.1987. The results are the mean on 16 different plots.

\begin{tabular}{|c|c|c|c|c|c|c|}
\hline $\begin{array}{l}\text { volume } \\
\text { weight } \\
\mathrm{g} \mathrm{cm}^{-3}\end{array}$ & $\begin{array}{l}\text { claya, Organic C } \\
\% \quad \%\end{array}$ & $\begin{array}{l}\mathrm{pH} \\
\left(\mathrm{CaCl}_{2}\right)\end{array}$ & $\begin{array}{l}{ }^{134} \mathrm{Cs} \text {, } \\
\text { mean }\end{array}$ & $\begin{array}{c}\mathrm{Bq} \mathrm{kg}^{-1} \\
\text { range }\end{array}$ & $\begin{array}{l}{ }^{137} \mathrm{Cs} \text {, } \\
\text { mean }\end{array}$ & $\begin{array}{r}\mathrm{Bq} \mathrm{kg}^{-1} \\
\text { range }\end{array}$ \\
\hline
\end{tabular}

Experiment 1

$\begin{array}{rrrrrrrrr}\text { clay soil } & & & & & & & \\ 0-20 \mathrm{~cm} & 1.0 & 61 & 3.7 & 5.5 & 5.0 & (3.1-7.3) & 20 & (15-27) \\ 20-40 \mathrm{~cm} & 1.0 & 73 & 2.0 & 5.6 & 7.2 & (0-13) & 26 & (10-40) \\ & & & & & & & & \\ \text { y loam soil } & & 13 & 2.6 & 6.3 & 6.8 & (4.5-12) & 24 & (17-38) \\ 0-20 \mathrm{~cm} & 1.2 & 130.5 & 6.1 & 2.9 & (0-5.2) & 11 & (1.2-18)\end{array}$

Experiment 2

$\begin{array}{rrrrrrrrr}\begin{array}{r}\text { clay soil } \\ 0-20 \mathrm{~cm}\end{array} & 1.0 & 49 & 2.8 & 5.5 & 6.3 & (2.2-11) & 22 & (12-34) \\ 20-40 \mathrm{~cm} & 1.1 & 61 & 1.3 & 5.7 & 2.2 & (0-4.1) & 8.4 & (3.6-16) \\ & & & & & & & & \\ \text { y loam soil } & & & & & & & \\ 0-20 \mathrm{~cm} & 1.1 & 36 & 2.7 & 6.2 & 5.9 & (2.6-11) & 21 & (11-35) \\ 20-40 \mathrm{~cm} & 1.1 & 45 & 1.5 & 6.3 & <2 & & 3.8 & (1.7-8.2)\end{array}$

"particle size $<0.002 \mathrm{~mm}$ 
had to be concentrated by dry ashing at $450^{\circ} \mathrm{C}$. In 1989, all samples were ashed, and pressed into tablets before measurement in cylindrical geometry (volume $30 \mathrm{~cm}^{3}$ ).

Because the activities in grain and straw were close to the detection limits, the error of the measurement of ${ }^{137} \mathrm{Cs}$ can be as big as $20-30 \%$.

\section{Results and discussion}

In $1987,{ }^{40} \mathrm{~K},{ }^{134} \mathrm{Cs},{ }^{137} \mathrm{Cs}$ and small amounts of ${ }^{106} \mathrm{Ru}$ and ${ }^{125} \mathrm{Sb}$ were detected in soil samples before the addition of sludge. The concentrations of ${ }^{134} \mathrm{Cs}$ and ${ }^{137} \mathrm{Cs}$ in the soil are presented in Table 2 .

The largest amounts of radionuclides were detected at a depth of $20-40 \mathrm{~cm}$ in the clay soil in experiment 1 established in spring 1987. In spring 1986, the deposition had fallen on the surface of the field and in the autumn, when the field was ploughed, the active surface layer was turned down to about $20 \mathrm{~cm}$. During the sampling the cores were cut at $20 \mathrm{~cm}$ and $40 \mathrm{~cm}$. Therefore, the total amount of activity down to $40 \mathrm{~cm}$ was used for the calculation of transfer factors.

The mean ${ }^{137} \mathrm{Cs}$ concentration in the soils (down to $40 \mathrm{~cm}$ ) before the sludge treatment was 23 and
$15 \mathrm{~Bq} \mathrm{~kg}^{-1}$ dry weight in clay and 18 and $12 \mathrm{~Bq}$ $\mathrm{kg}^{-1}$ dry weight in sandy loam and clay loam soil in experiments 1 and 2, respectively.

The amount of ${ }^{137} \mathrm{Cs}$ per square meter (down to $40 \mathrm{~cm}$ ) was calculated using the concentration of ${ }^{137} \mathrm{Cs} \mathrm{Bq} \mathrm{kg}^{-1}$ dry weight and the volume weight (bulk density) of dry soil samples. In Finland the ratio of ${ }^{134} \mathrm{Cs}$ to ${ }^{137} \mathrm{Cs}$ in the Chernobyl fallout on 1 May, 1986 was 0.6 (ARVELA et al. 1987). Using this ratio, the concentration of ${ }^{134} \mathrm{Cs}$ and taking into account the radioactive decay the proportion of "old" fallout ${ }^{137} \mathrm{Cs}$ originating from nuclear weapons tests was estimated to be about $2000 \mathrm{~Bq}$ $\mathrm{m}^{-2}$ in the experimental soil. The Chernobyl accident added $4000-7000 \mathrm{~Bq} \mathrm{~m}^{-2}$ of ${ }^{137} \mathrm{Cs}$ to this soil. The addition of sludge still increased the amount of ${ }^{137} \mathrm{Cs}$ by $10000-12000 \mathrm{~Bq} \mathrm{~m}^{-2}$ to a total of $16000-$ $21000 \mathrm{~Bq} \mathrm{~m}^{-2}$.

The average dry matter yields of grain and straw are given in Tables 3 and 4 . The addition of sludge didn't cause any statistically significant differences between the grain yields. The straw yields were in 1987 significantly higher in those plots where sludge was added than in the plots without sludge addition.

In 1988, the grain yields and especially the straw yields were remarkably lower than normal. This

Table 3. The average dry matter yields of grain and straw in experiment 1 and differences between the treatments.

\begin{tabular}{|c|c|c|c|c|c|c|c|}
\hline \multirow[t]{3}{*}{ Cereal/Soil } & \multirow[t]{3}{*}{ Year } & \multicolumn{3}{|c|}{ Grain } & \multicolumn{3}{|c|}{ Straw } \\
\hline & & \multicolumn{2}{|c|}{$\mathrm{kg} \mathrm{ha}^{-1}$} & \multirow[b]{2}{*}{$\begin{array}{r}\text { Differ- } \\
\text { ence }^{1}\end{array}$} & \multicolumn{2}{|c|}{$\mathrm{kg} \mathrm{ha}^{-1}$} & \multirow[b]{2}{*}{$\begin{array}{r}\text { Differ- } \\
\text { ence }\end{array}$} \\
\hline & & $\begin{array}{l}\text { no } \\
\text { sludge }\end{array}$ & sludge & & $\begin{array}{l}\text { no } \\
\text { sludge }\end{array}$ & sludge & \\
\hline \multicolumn{8}{|l|}{ Spring wheat } \\
\hline \multirow{2}{*}{ clay } & -87 & 2260 & 2190 & NS & 3280 & 4120 & $\mathrm{XX}$ \\
\hline & -88 & 2110 & 2130 & NS & 1090 & 1100 & NS \\
\hline \multirow[t]{2}{*}{ sandy loam } & -87 & 2370 & 1990 & NS & 3850 & 4750 & $\mathrm{X}$ \\
\hline & -88 & 2270 & 2300 & NS & 1950 & 2040 & NS \\
\hline \multicolumn{8}{|l|}{ Barley } \\
\hline \multirow{2}{*}{ clay } & -87 & 2980 & 3270 & NS & 2090 & 3110 & $\mathrm{XX}$ \\
\hline & -88 & 2580 & 2150 & $\mathrm{X}$ & 670 & 580 & NS \\
\hline \multirow[t]{2}{*}{ sandy loam } & -87 & 3960 & 3660 & NS & 2920 & 3790 & $\mathrm{XX}$ \\
\hline & -88 & 3600 & 3520 & NS & 1960 & 1910 & NS \\
\hline
\end{tabular}

\footnotetext{
${ }^{1}$ Statistically significant differences in yields at the 0.05 level of significance are indicated by $\mathrm{X}$ at the 0.01 level of significance are indicated by $\mathrm{XX}$ $\mathrm{NS}=$ not significant
} 
was caused by the weather conditions during the growing season. The beginning of the summer was warmer and drier than normal. In July, there were many thundery rains and the precipitation was higher than normal (Ilmatieteen laitos 1988).

Of the nuclides originating from the Chernobyl fallout, only ${ }^{134} \mathrm{Cs}$ and ${ }^{137} \mathrm{Cs}$ were detected in the experimental plants. The concentrations of ${ }^{134} \mathrm{Cs}$ were so low that this isotope was detected mainly in 1987 and only in spring wheat and barley grown in the sludge treated plots. The mean concentrations of ${ }^{137} \mathrm{Cs}$ and the range of concentrations in spring wheat and barley samples are given in Tables 5 and 6 . In the sludge treated plots the mean concentrations of ${ }^{137} \mathrm{Cs}$ in grain varied from 1 to $3 \mathrm{~Bq} \mathrm{~kg}{ }^{-1}$ dry weight in the first growing season and from 0.2 to $0.8 \mathrm{~Bq} \mathrm{~kg}^{-1}$ in the second growing season. In the treatments without sludge addition the mean concentrations were 0.2 $0.3 \mathrm{~Bq} \mathrm{~kg}^{-1}$ in $1987,0.1-0.4 \mathrm{~Bq} \mathrm{~kg}^{-1}$ in 1988 and $0.07-$ $0.08 \mathrm{~Bq} \mathrm{~kg}^{-1}$ in 1989 .

The average concentration of ${ }^{137} \mathrm{Cs}$ in wheat in Finland was $0.05 \mathrm{~Bq} \mathrm{~kg}^{-1}$ dry weight in 1985 (STUK 1987) and after the Chernobyl accident in 1986 it was $2.6 \mathrm{~Bq} \mathrm{~kg}^{-1}$ (RANTAVAARA and HAUKKA 1987). In 1987 the average concentration of ${ }^{137} \mathrm{Cs}$ in wheat was $0.4 \mathrm{~Bq} \mathrm{~kg}^{-1}$ and in barley $0.6 \mathrm{~Bq} \mathrm{~kg}^{-1}$
(RANTAVAARA 1991).

The mean concentrations of ${ }^{137} \mathrm{Cs}$ in the grain of spring wheat and barley were about equal, or a little bit higher in spring wheat after sludge addition in the first experimental year. The mean concentrations of ${ }^{137} \mathrm{Cs}$ in straw were higher in barley than in spring wheat. Application of sludge increased the concentration of ${ }^{137} \mathrm{Cs}$ in grain 2-12 times and in straw 1-6 times as compared with crops grown in the control plots. The variations in different plots were high. The large variations in the activity concentrations were obviously due to the uneven distribution of radionuclides in the soil, to the heterogeneity of the sludge and the uneven spread of the sludge on the fields.

In experiment 2 of the first growing season (in 1988) was the concentration of ${ }^{137} \mathrm{Cs}$ in spring wheat and barley grown in plots to which sludge was added of the same magnitude as the concentration of ${ }^{137} \mathrm{Cs}$ found in the first growing season (in 1987) in experiment 1 in the plots with the corresponding treatment. There wasn't any significant difference in the concentrations of ${ }^{137} \mathrm{Cs}$ in grain whether the sludge was added in the previous autumn before ploughing or after ploughing in the spring before harrowing.

Table 4.The average dry matter yields of grain and straw in experiment 2 and differences betwwen the treatments.

\begin{tabular}{|c|c|c|c|c|c|c|c|}
\hline \multirow[t]{3}{*}{ Cereal/Soil } & \multirow[t]{3}{*}{ Year } & \multicolumn{3}{|c|}{ Grain } & \multicolumn{3}{|c|}{ Straw } \\
\hline & & \multicolumn{2}{|c|}{$\mathrm{kg} \mathrm{ha}^{-1}$} & \multirow[b]{2}{*}{$\begin{array}{r}\text { Differ- } \\
\text { ence }^{1}\end{array}$} & \multicolumn{2}{|c|}{$\mathrm{kg} \mathrm{ha}^{-1}$} & \multirow[b]{2}{*}{$\begin{array}{r}\text { Differ- } \\
\text { ence }^{1}\end{array}$} \\
\hline & & $\begin{array}{l}\text { no } \\
\text { sludge }\end{array}$ & sludge & & $\begin{array}{l}\text { no } \\
\text { sludge }\end{array}$ & sludge & \\
\hline \multicolumn{8}{|l|}{ Spring wheat } \\
\hline \multirow{2}{*}{ clay } & -88 & 1620 & 1720 & NS & 790 & 900 & NS \\
\hline & -89 & 3530 & 3730 & NS & 1290 & 1500 & NS \\
\hline \multirow[t]{2}{*}{ sandy loam } & -88 & 1980 & 1990 & NS & 1110 & 1200 & NS \\
\hline & -89 & 3300 & 3330 & NS & 1450 & 1550 & NS \\
\hline \multicolumn{8}{|l|}{ Barley } \\
\hline \multirow[t]{2}{*}{ clay } & -88 & 2200 & 2230 & NS & 640 & 560 & NS \\
\hline & -89 & 3730 & 4130 & NS & 1470 & 1710 & NS \\
\hline \multirow[t]{2}{*}{ sandy loam } & -88 & 2670 & 2930 & NS & 870 & 1060 & NS \\
\hline & -89 & 4010 & 4160 & NS & 1890 & 2190 & NS \\
\hline
\end{tabular}

\footnotetext{
${ }^{1}$ Statistically significant differences in yields at the 0.05 level of significance are indicated by $\mathrm{X}$ at the 0.01 level of significance are indicated by $\mathrm{XX}$ $\mathrm{NS}=$ not significant
} 
The main part of total activity is mostly translocated to the straw in the grain crop. Many earlier experiments have shown that the uptake in the straw is greater than in the grain (ØHLENSCHLAEGER and GISSEL-NIELSEN 1989).

The statistical comparison between the concentration of ${ }^{137} \mathrm{Cs}$ in grain and straw grown in soils fertilized with different way were used in analysis of variance and t-test. Results are given in Tables 5 and 6.

In experiment 1 in 1987, the random variation of the concentration in spring wheat at different plots was so great that the analysis of variance did not show any significant difference (except on sandy loam).

In experiment 2 , the differences were statistically significant in both crops and both soil types in both experimental years. In the second experimental year the differences were statistically more significant on sandy soil both in grain and straw. The variations in the yields in different years did not show any significant effect on the concentrations of ${ }^{137} \mathrm{Cs}$ in grain. The more significant effect was the variation in the concentration of ${ }^{137} \mathrm{Cs}$ in soil and the time what ${ }^{137} \mathrm{Cs}$ has been in soil.

The concentration ratio (CR) for radiocesium from soil (down to $40 \mathrm{~cm}$ ) to grain was defined as $\mathrm{Bq} \mathrm{kg}^{-1}$ grain per $\mathrm{Bq} \mathrm{kg}{ }^{-1}$ soil (or soil and sludge). The mean $\mathrm{CR}$ values for ${ }^{137} \mathrm{Cs}$ ranged between 0.02 and 0.07 in the first experimental year in both experiments on soils to which sludge was added. In the second experimental year the values ranged between 0.005 and 0.02 . There was no statistically significant difference between CR values whether the sludge was added in the previous autumn before ploughing or after ploughing before harrowing in

Table 5. The mean concentrations and the ranges of ${ }^{137} \mathrm{Cs}\left(\mathrm{Bq} \mathrm{kg}^{-1}\right)$ in grain and straw in experiment 1 (sludge applied in spring 1987) and differences between treatments.

\begin{tabular}{|c|c|c|c|c|c|c|c|}
\hline \multirow[t]{3}{*}{ Cereal/Soil } & \multirow[t]{3}{*}{ Year } & \multicolumn{3}{|c|}{ Grain } & \multicolumn{3}{|c|}{ Straw } \\
\hline & & \multicolumn{2}{|c|}{$\mathrm{Bq} \mathrm{kg}^{-1}$} & \multirow[b]{2}{*}{$\begin{array}{l}\text { Differ- } \\
\text { ence }^{1}\end{array}$} & \multicolumn{2}{|c|}{$\mathrm{Bq} \mathrm{kg}^{-1}$} & \multirow[b]{2}{*}{$\begin{array}{r}\text { Differ- } \\
\text { ence }^{1}\end{array}$} \\
\hline & & $\begin{array}{l}\text { no } \\
\text { sludge }\end{array}$ & sludge & & $\begin{array}{l}\text { no } \\
\text { sludge }\end{array}$ & sludge & \\
\hline \multirow{3}{*}{$\begin{array}{l}\text { Spring wheat } \\
\text { clay }\end{array}$} & & & & & & & \\
\hline & -87 & $\begin{array}{c}0.37 \\
(0.24-0.56)\end{array}$ & $\begin{array}{c}2.2 \\
(0.58-3.6)\end{array}$ & NS & $\begin{array}{c}0.78 \\
(0.5-1.1)\end{array}$ & $\begin{array}{c}1.4 \\
(0.73-2.1)\end{array}$ & NS \\
\hline & -88 & $\begin{array}{c}0.14 \\
(0.098-0.19)\end{array}$ & $\begin{array}{c}0.26 \\
(0.12-0.47)\end{array}$ & NS & 0.62 & $\begin{array}{c}0.57 \\
(0.44-0.65)\end{array}$ &.$^{2}$ \\
\hline \multirow[t]{2}{*}{ sandy loam } & -87 & $\begin{array}{c}0.34 \\
(0.15-0.71)\end{array}$ & $\begin{array}{c}2.9 \\
(1.4-5.3)\end{array}$ & $\mathrm{X}$ & $\begin{array}{c}0.67 \\
(0.39-1.2)\end{array}$ & $\begin{array}{c}3.9 \\
(1.9-7.8)\end{array}$ & NS \\
\hline & -88 & 0.42 & $\begin{array}{c}0.65 \\
(0.30-1.2)\end{array}$ & - & $\begin{array}{c}0.68 \\
(0.59-0.85)\end{array}$ & $\begin{array}{c}1.3 \\
(0.68-1.8)\end{array}$ & $\mathrm{X}$ \\
\hline \multicolumn{8}{|l|}{ Barley } \\
\hline \multirow[t]{2}{*}{ clay } & -87 & $\begin{array}{c}0.22 \\
(0.12-0.40)\end{array}$ & $\begin{array}{c}1.0 \\
(0.79-1.1)\end{array}$ & $\mathrm{XX}$ & $\begin{array}{c}0.9 \\
(0.66-1.2)\end{array}$ & $\begin{array}{c}3.9 \\
(3.4-4.8)\end{array}$ & $\mathrm{XX}$ \\
\hline & -88 & $\begin{array}{l}0.12 \\
(0-0.18)\end{array}$ & $\begin{array}{c}0.23 \\
(0.15-0.37)\end{array}$ & NS & 0.59 & $\begin{array}{c}1.0 \\
(0.95-1.11)\end{array}$ & - \\
\hline \multirow[t]{2}{*}{ sandy loam } & -87 & $\begin{array}{c}0.33 \\
(0.11-0.79)\end{array}$ & $\begin{array}{c}1.9 \\
(1.1-2.4)\end{array}$ & $\mathrm{XX}$ & $\begin{array}{c}1.2 \\
(0.86-1.5)\end{array}$ & $\begin{array}{c}5.7 \\
(4.5-6.7)\end{array}$ & $\mathrm{XX}$ \\
\hline & -88 & 0.19 & $\begin{array}{c}0.66 \\
(0.53-1.04)\end{array}$ & - & $\begin{array}{c}1.3 \\
(0.92-1.8)\end{array}$ & $\begin{array}{c}1.3 \\
(0.81-1.7)\end{array}$ & NS \\
\hline
\end{tabular}

\footnotetext{
Statistically significant differences in concentrations at the 0.05 level of significance are indicated by $\mathrm{X}$ at the 0.01 level of significance are indicated by $\mathrm{XX}$ NS $=$ not significant

${ }^{2}$ the samples from four replicates are bulked
} 
the following spring. In soil to which no sludge was added the CR values were in 1987 (in the second year after the fallout from Chernobyl) 0.01-0.02, in $19880.006-0.03$, in $19890.004-0.006$. The results indicate that sludge has a significant influence on the concentration of radiocesium in grain crops only during the first year after sludge addition.

For the sludge-treated soils varied the average transfer factor (TF) of ${ }^{137} \mathrm{Cs}$ from soil to plant defined as $\mathrm{Bq} \mathrm{ha}^{-1}$ plant (grain and straw) per $\mathrm{Bq} \mathrm{ha} \mathrm{a}^{-1}$ soil (or soil and sludge) in first experimental years (1987 and 1988 ) from $24 \times 10^{-6}$ to $150 \times 10^{-6}$ and in the second experimental year (1988 and 1989) from $5.6 \times 10^{-6}$ to $52 \times 10^{-6}$ and for the control soils from $10 \times 10^{-6}$ to 58 $\times 10^{-6}$ and from $8.4 \times 10^{-6}$ to $52 \times 10^{-6}$, respectively (see Table 7). In the first growing season there were distinct differences in transfer factors between the treatments where sludge was added and the treatments without sludge addition. In the second year, no differences were found in experiment 1 . In experiment 2 there were differences in the TF factor also in the second growing season.

The transfer factors were greater in those plots to which sludge was added. The fact that the sludge was over winter in soil did not change the plant availability of cesium in sludge in the first growing season after addition. In the following year the residual effect of the sludge was little.

There were in the first year large variations in activities of plants between different replicates. These variations diminished during the second year. The differences between the plots treated with different way diminished also during the second year. However, in the experimental plots where sludge was added was also in the second year higher activities in plants than in the plots without

Table 6. The mean concentrations and the ranges of ${ }^{137} \mathrm{Cs}\left(\mathrm{Bq} \mathrm{kg}^{-1}\right)$ in grain and straw in experiment 2 (Sludge applied in autumn 1987) and differences between the treatments.

\begin{tabular}{|c|c|c|c|c|c|c|c|}
\hline \multirow[t]{3}{*}{ Cereal/Soil } & \multirow[t]{3}{*}{ Year } & \multicolumn{3}{|c|}{ Grain } & \multicolumn{3}{|c|}{ Straw } \\
\hline & & \multicolumn{2}{|c|}{$\mathrm{Bq} \mathrm{kg}^{-1}$} & \multirow[b]{2}{*}{$\begin{array}{l}\text { Differ- } \\
\text { ence }^{1}\end{array}$} & \multicolumn{2}{|c|}{$\mathrm{Bq} \mathrm{kg}^{-1}$} & \multirow[b]{2}{*}{$\begin{array}{r}\text { Differ- } \\
\text { ence }^{1}\end{array}$} \\
\hline & & $\begin{array}{l}\text { no } \\
\text { sludge }\end{array}$ & sludge & & $\begin{array}{l}\text { no } \\
\text { sludge }\end{array}$ & sludge & \\
\hline \multirow[t]{2}{*}{$\begin{array}{l}\text { Spring wheat } \\
\text { clay }\end{array}$} & -88 & $\begin{array}{c}0.16 \\
(0.12-0.20)\end{array}$ & $\begin{array}{c}1.0 \\
(0.88-1.23)\end{array}$ & $\mathrm{XX}$ & $\begin{array}{c}0.59 \\
(0.44-0.77)\end{array}$ & $\begin{array}{c}2.2 \\
(1.6-2.8)\end{array}$ & $\mathrm{XX}$ \\
\hline & -89 & $\begin{array}{c}0.080 \\
(0.053-0.10)\end{array}$ & $\begin{array}{c}0.29 \\
(0.15-0.42)\end{array}$ & $\mathrm{X}$ & $\begin{array}{c}0.32 \\
(0.27-0.36)\end{array}$ & $\begin{array}{c}0.59 \\
(0.37-0.70)\end{array}$ & $\mathrm{X}$ \\
\hline \multirow[t]{2}{*}{ clay loam } & -88 & $\begin{array}{c}0.19 \\
(0.18-0.22)\end{array}$ & $\begin{array}{c}2.4 \\
(1.6-3.4)\end{array}$ & $\mathrm{XX}$ & $\begin{array}{c}0.64 \\
(0.48-0.77)\end{array}$ & $\begin{array}{c}3.8 \\
(2.4-5.4)\end{array}$ & $\mathrm{XX}$ \\
\hline & -89 & $\begin{array}{c}0.079 \\
(0.057-0.094)\end{array}$ & $\begin{array}{c}0.44 \\
(0.20-0.53)\end{array}$ & $\mathrm{XX}$ & $\begin{array}{c}0.27 \\
(0.19-0.32)\end{array}$ & $\begin{array}{c}1.03 \\
(0.34-1.45)\end{array}$ & $\mathrm{xX}$ \\
\hline \multirow[t]{2}{*}{ clay } & -88 & $\begin{array}{c}0.39 \\
(0.13-0.81)\end{array}$ & $\begin{array}{c}0.95 \\
(0.54-1.24)\end{array}$ & $\mathrm{X}$ & $\begin{array}{c}0.97 \\
(0.86-1.10)\end{array}$ & $\begin{array}{c}3.8 \\
(2.5-5.5)\end{array}$ & $\mathrm{XX}$ \\
\hline & -89 & $\begin{array}{c}0.079 \\
(0.043-0.12)\end{array}$ & $\begin{array}{c}0.31 \\
(0.20-0.46)\end{array}$ & $\mathrm{X}$ & $\begin{array}{c}0.36 \\
(0.28-0.44)\end{array}$ & $\begin{array}{c}0.94 \\
(0.34-1.45)\end{array}$ & NS \\
\hline \multirow[t]{2}{*}{ clay loam } & -88 & $\begin{array}{c}0.31 \\
(0.083-0.84)\end{array}$ & $\begin{array}{c}2.2 \\
(1.2-4.0)\end{array}$ & $\mathrm{X}$ & $\begin{array}{c}0.80 \\
(0.50-1.10)\end{array}$ & $\begin{array}{c}4.5 \\
(3.0-5.8)\end{array}$ & $\mathrm{XX}$ \\
\hline & -89 & $\begin{array}{c}0.068 \\
(0.051-0.11)\end{array}$ & $\begin{array}{c}0.81 \\
(0.31-1.07)\end{array}$ & $\mathrm{XX}$ & $\begin{array}{c}0.41 \\
(0.31-0.53)\end{array}$ & $\begin{array}{c}2.1 \\
(1.2-2.6)\end{array}$ & $\mathrm{XX}$ \\
\hline
\end{tabular}

\footnotetext{
' Statistically significant differences in concentrations at the 0.05 level of significance are indicated by $\mathrm{X}$ at the 0.01 level of significance are indicated by $\mathrm{XX}$ $\mathrm{NS}=$ not significant
} 
sludge addition. After the sludge was added, the activities and CR and TF values were lower on clay soil than on sandy loam and clay loam soils, both in the first and second growing seasons. Clay soil fixes cesium added with sludge. Many investigations have also shown that cesium migration and plant availability depend on the content and type of clay and on the organic matter and the potassium content of the soil. The transfer of ${ }^{137} \mathrm{Cs}$ from soil to crop will decrease with increasing clay content and be higher from organic soils (MASCANZONI 1989, HAAK 1990, ERIKSSON 1990).

Table 7. The transfer factor (TF) of ${ }^{137} \mathrm{Cs}$ from soil to plant and differences between the treatment.

Experiment 1

\begin{tabular}{|c|c|c|c|c|c|c|c|}
\hline \multirow[t]{3}{*}{ Soil/Cereal } & \multirow{3}{*}{$\begin{array}{l}\text { Sludge } \\
\text { applica- } \\
\text { tion } \\
\text { t D.M./ha }\end{array}$} & \multicolumn{5}{|c|}{$\mathrm{TF} \times 10^{6}$} & \multirow[b]{3}{*}{$\begin{array}{l}\text { Differ- } \\
\text { ence }^{1}\end{array}$} \\
\hline & & \multicolumn{2}{|c|}{1987} & & \multicolumn{2}{|c|}{1988} & \\
\hline & & mean & range & $\begin{array}{l}\text { Differ- } \\
\text { ence }^{1}\end{array}$ & $\overline{\text { mean }}$ & range & \\
\hline \multicolumn{8}{|l|}{ Clay } \\
\hline \multirow[t]{2}{*}{ Spring wheat } & 0 & 35 & $(25-59)\}$ & \multirow{2}{*}{ NS } & 9.4 & & \multirow[t]{2}{*}{2} \\
\hline & 22 & 46 & $(27-69)\}$ & & 5.6 & $(3.3-8.6)$ & \\
\hline \multirow[t]{2}{*}{ Barley } & 0 & 32 & $(24-37))$ & \multirow{2}{*}{ XX } & 8.8 & & \multirow[t]{2}{*}{2} \\
\hline & 22 & 79 & $(63-110)\}$ & & 6.0 & $(4.7-6.8)$ & \\
\hline \multicolumn{8}{|l|}{ Sandy loam } \\
\hline \multirow[t]{2}{*}{ Spring wheat } & 0 & 40 & $(32-52)$ & \multirow[b]{2}{*}{ NS } & 28 & & \multirow[t]{2}{*}{2} \\
\hline & 22 & 120 & $(59-230)\}$ & & 20 & $(11-28)$ & \\
\hline \multirow[t]{2}{*}{ Barley } & 0 & 58 & $(23-110))$ & \multirow[b]{2}{*}{$\mathrm{X}$} & 34 & & \multirow[t]{2}{*}{2} \\
\hline & 22 & 150 & $(100-190)\}$ & & 24 & $(16-29)$ & \\
\hline
\end{tabular}

Experiment 2

\begin{tabular}{|c|c|c|c|c|c|c|c|}
\hline \multirow[t]{3}{*}{ Soil/Cereal } & \multirow{3}{*}{$\begin{array}{l}\text { Sludge } \\
\text { applica- } \\
\text { tion } \\
\text { t D.M./ha }\end{array}$} & \multicolumn{5}{|c|}{$\mathrm{TF} \times 10^{6}$} & \multirow[b]{3}{*}{$\begin{array}{l}\text { Differ- } \\
\text { ence }^{1}\end{array}$} \\
\hline & & \multicolumn{2}{|c|}{1988} & & \multicolumn{2}{|c|}{1989} & \\
\hline & & mean & range & $\begin{array}{l}\text { Differ- } \\
\text { ence }^{1}\end{array}$ & mean & range & \\
\hline \multicolumn{8}{|l|}{ Clay } \\
\hline Spring wheat & $\begin{array}{r}0 \\
22\end{array}$ & $\begin{array}{l}10 \\
24\end{array}$ & $\left.\begin{array}{r}(6.7-13) \\
(20-28)\end{array}\right\}$ & $\mathrm{XX}$ & $\begin{array}{r}8.4 \\
17\end{array}$ & $\left.\begin{array}{l}(7.7-9.2) \\
(11-23)\end{array}\right\}$ & $\mathrm{X}$ \\
\hline Barley & $\begin{array}{r}0 \\
22\end{array}$ & $\begin{array}{l}26 \\
26\end{array}$ & $\left.\begin{array}{l}(11-49) \\
(16-34)\end{array}\right\}$ & NS & $\begin{array}{l}13 \\
16\end{array}$ & $\left.\begin{array}{l}(8.4-17) \\
(9.0-21)\end{array}\right\}$ & NS \\
\hline \multicolumn{8}{|l|}{ Clay loam } \\
\hline Spring wheat & $\begin{array}{r}0 \\
22\end{array}$ & $\begin{array}{l}20 \\
65\end{array}$ & $\left.\begin{array}{r}(15-26) \\
(39-100)\end{array}\right\}$ & $\mathrm{X}$ & $\begin{array}{l}13 \\
17\end{array}$ & $\left.\begin{array}{l}(7.7-19) \\
(12-22)\end{array}\right\}$ & NS \\
\hline Barley & $\begin{array}{r}0 \\
22\end{array}$ & $\begin{array}{l}21 \\
74\end{array}$ & $\left.\begin{array}{r}(13-29) \\
(44-140)\end{array}\right\}$ & $\mathrm{X}$ & $\begin{array}{l}18 \\
52\end{array}$ & $\left.\begin{array}{l}(8.8-35) \\
(31-59)\end{array}\right\}$ & $\mathrm{XX}$ \\
\hline
\end{tabular}

' Statistically significant differences in transfer factors at the 0.05 level of significance are indicated by X at the 0.01 level of significance are indicated by $\mathrm{XX}$ $\mathrm{NS}=$ not significant

${ }^{2}$ The sample from four replicates are bulked 


\section{References}

Arvel.a, H., BlomQvist, L., Lemmel Ā, H., Savolainen, A.L. \& SARKKULA, S. 1987. Environmental gamma radiation measurements in Finland and the influence of the meteorological conditions after the Chernobyl accident in 1986. STUK-A65. Suppl. 10 to Ann. Rep. STUKA55. Finnish Centre for Radiation and Nuclear Safety. $40 \mathrm{p}$.

ERIKSSON, Å. 1990. Adsorption and residence of cesium in soils and organic matter. In: Deposition and transfer of radionuclides in nordic terrestric environment. NJF-utredning/rapport nr. 59: 3-12.

HAAK, E. 1990. Long term transfer of Cs and $\mathrm{Sr}$ to agricultural soils. In: Deposition and transfer of radionuclides in nordic terrestric environment. NJF-utredning/rapport nr. 59: 28-39.

Ilmatieteenlaitos - Meteorologiska institutet. 1988. Kuukausikatsaus Suomen ilmastoon. Yhteenveto 1988. 8 p.

LundSTRÖ, Y. 1987. Personal communication with Y. Lundström. City of Helsinki, Water and Sewage Authority.

Mascanzoni, D. 1989. Plant Uptake of Activation and Fission Products in a Long Term Field Study. J. Environ. Radioactivity 10: 233-249.

Medicinalsstyrelsens circulär. 1637/1977. Instruktioner om forrebyggande av hälsorisker vid uttnytjande av avloppsslam. $13 \mathrm{p}$.

ØhlensChlaeger, M. \& Gissel-Nielsen, G. 1989. Transfer of Radiocesium to Barley, Rye Grass and Pea. Risø-M2831. $20 \mathrm{p}$.

PuhakaInen, M. 1986. Artificial gammaradionuclides in sewer water and sludge (Situation before 26.4.1986). English Summary. STUK-B-VALO 43. Finnish Centre for Radiation and Nuclear Safety. 24 p.

-, Rahola, T. \& SuOMElA, M. 1987. Radioactivity of sludge after the Chernobyl accident in 1986. STUKA68. Suppl. 13 to Ann. Rep. STUK-A55. Finnish Centre for Radiation and Nuclear Safety. 29 p.

RANTAVAARA, A. 1991. Radioactive substances of foodstuffs in Finland in 1987, STUK-A78. Suppl. 4 to Ann. Rep. STUK-A74. Finnish Centre for Radiation and
Nuclear Safety.

— \& HAUKKA, S. 1987. Radioactivity of milk, meat, cereals and other agricultural products in Finland after the Chernobyl accident in 1986. STUK-A58. Suppl. 3 to Ann. Rep. STUK-A55. Finnish Centre for Radiation and Nuclear Safety. 105 p.

SiPPOLA, J. 1982. A comparison between a dry-combustion method and a rapid wet-combustion method for determining soil organic carbon. Ann. Agric. Fenn. 21: 146148.

STUK, Finnish Centre for Radiation and Nuclear Safety. 1987. Foodstuffs other than milk. In:Studies on environmental radioactivity in Finland 1984-1985. Ann. Rep. STUK-54. p. 59-89.

TARES, T. \& SipPOLA, J. 1987. Changes in pH, in electrical conductivity and in the extractable amounts of mineral elements in soil, and the utilization and losses of the elements in some field experiments. Acta Agric. Scand. Suppl. 20: 90-113.

ToIVAnen, E. 1987. Personal communication with E. Toivanen. City of Helsinki, Water and Sewage Authority, Water Dep. May 1987.

VuORINEN, J. \& MÄKITIE, O. 1955. The method of soil testing in use in Finland. Agrogeol. Publ. 63: 1-44.

Ympäristöministeriö. 1991. Ohje 4. Puhdistamolietteen käyttö maanviljelyssä. (Användningen av slam från reningsverk inom jordbruket). 43 p.

Manuscript received June 1991

Marketta Puhakainen

Finnish Centre for Radiation and Nuclear Safety

Box 268

SF-00101 Helsinki, Finland

Toivo Ylăranta

Agricultural Research Centre of Finland

Institute of Environmental Research

SF-31600 Jokioinen, Finland 


\title{
SELOSTUS
}

\section{Viljelymaahan lisätyn kontaminoituneen jätevesilietteen vaikutus kevätvehnän ja ohran radionuklidipitoisuuksiin}

\author{
Marketta PuhaKainen ja Toivo Yläranta \\ Säteilyturvakeskus ja Maatalouden tutkimuslaitos
}

Kenttăkokein selvitettiin jätevesilietteen sisăltämăn radioaktiivisen cesiumin siirtymistä kevătvehnäăn ja ohraan savi-, hieta- ja hiuesavimaasta. Kokeet tehtiin Jokioisissa Maatalouden tutkimuskeskuksessa. Osa kokeesta tehtiin levittämällä liete kynnettyyn peltoon keväällä 1987 ennen maanmuokkausta (koe 1), osa lietettä levitettiin syksyllä 1987 ennen kyntöä (koe 2). Kokeet olivat kaksivuotisia.

Käytetty liete oli Kyläsaaren puhdistamolla keväällä 1986 muodostunutta mädätettyä lietettă, joka sisälsi runsaasti Tshernobyl-laskeumasta peräisin olevia radionuklideja. Sen ${ }^{137} \mathrm{Cs}$-pitoisuus oli $4700-5300 \mathrm{~Bq} / \mathrm{kg}$ kuiva-ainetta. Lietteessă oli mukana raakavedenpuhdistamolta peräisin olevaa $\mathrm{Al}-$ sulfaatilla saostettua sakkaa, jonka radioaktiivisen cesiumin pitoisuus oli korkea.

Lietettä levitettiin pellolle 20 tonnia kuiva-ainetta hehtaarille. Verranneruutuihin, joihin ei lisătty lietettä, lisăttiin NPK-lannoitetta, niin että kasvien käytettävisså olevien ravinteiden määrät olivat likimain yhtä suuret kaikissa koeruu- duissa.

${ }^{137} \mathrm{Cs}$ :n siirtyminen maasta kasviin oli suurin niissä ruuduissa, joihin lietettä oli lisätty. Jyvän ${ }^{137} \mathrm{Cs}$-pitoisuudet olivat 2-12 ja oljen 1-6 kertaa suuremmat lietelisäyksen jälkeen kuin ilman sitä. Lietelisäyksen jälkeen savimaassa kasvaneen viljan pitoisuudet ja siirtokertoimet olivat pienemmät kuin hietamaassa kasvaneen. Savimaa pidätti hietamaata voimakkaammin lietteen mukana tulevaa cesiumia. Ensimmäisenä satokautena siirtyi olkeen ja jyvăän yhteenså 0.002 - $0.015 \%$ maaperästä olevasta aktiivisuudesta, niissä ruuduissa, joihin lietettä oli lisätty. Seuraavana satokautena määrä oli noin kolmasosa tästä, eli samaa suuruusluokkaa kuin ilman lietelisäystä olevilla pelloilla. Lietteen lisäystapa ei vaikuttanut ${ }^{137} \mathrm{Cs}: \mathrm{n}$ siirtymiseen maasta kasviin. Molemmissa kokeissa ensimmäisen koevuoden siirtokertoimet olivat samaa suuruusluokkaa riippumatta siitä, oliko liete lisätty kevăăllă 1987 vai syksynă 1987 seuraavaa kasvukautta varten. 